\title{
PELAYANAN MASYARAKAT DI BIDANG PERALATAN OLAHRAGA ANAK UNTUK KELOMPOK KERJA GURU PENDIDIKAN FISIK GURU SD DI KOTA TEBING TINGGI TAHUN 2020
}

\author{
Imran Akhmad $^{1 *}$, Rahma Dewi ${ }^{2}$, Amir Supriadi ${ }^{3}$ \\ Jurusan Pendidikan Kepelatihan Olahraga, Fakultas Ilmu Keolahragaan, Universitas Negeri Medan ${ }^{123}$ \\ * Penulis Korespodensi: imran@unimed.ac.id
}

\begin{abstract}
Abstrak
Mitra kegiatan Program Kemitraan Masyarakat adalah kelompok kerja guru pendidikan jasmani kota Tebing Tinggi yang berjarak $60 \mathrm{~km}$ dari Universitas Negeri Medan. Guru Pendidikan Jasmani Olahraga Kesehatan tingkat Sekolah Dasar di Kota Tebing Tinggi memiliki beberapa permasalahan proses pembelajaran sehingga kecenderungan mutu pempelajaran Pendidikan Jasmani Olahraga Kesehatan belum maksimal. Adapun permasalahan mitra yang dihadapi selama ini adalah : (1) Kurangnya pengetahuan dan keterampilan Kelompok Kerja Guru Pendidikan Jasmani Olahraga Kesehatan Sekolah Dasar dalam memodifikasi Peralatan Olahraga bagi siswa dan atletik kids, penggunaannya dalam permainan dan analisis data hasil permainan, dan (2) Belum tersedia Peralatan Olahraga disekolahsekolah di kecamatan mitra yang dapat digunakan dalam rangka membantu proses pembelajaran Pendidikan Jasmai Sekolah Dasar. Kedua permasalahan tersebut menjadi dasar bahwa pembelajaran Pendidikan Jasmani Olahraga Kesehatan belum optimal. Metode yang akan digunakan pada kegiatan ini adalah adalah Pendampingan dan pemberdayaan. Adapun tahapan kegiatan sebagai berikut : 1) Penyediaan Permainan Olahraga Anak, (2) Pelatihan Pelaksanaan Atletik Kids dan teknik penilaian (3) Pelatihan Modifikasi Permainan Olahraga Anak, (4) Pelatihan penggunaan modifikasi Permainan Olahraga Anak dan (5) Perlombaan Atletik Kids. Hasil kegiatan : (1) Permainan Olahraga Anak telah diterima oleh ketua Kelompok Kerja Guru Pendidikan Jasmani Olahraga Kesehatan Sekolah Dasar Kota Tebing Tinggi, (2) Ketercapaian pelatihan penggunaan Permainan Olahraga Anak 92,5\%, (3) Ketercapaian indikator penilaian Permainan Olahraga Anak sebesar 89,5\%, dan (4) Ketercapaian modifikasi Permainan Olahraga Anak 93\%. Program kegiatan Pengabdian Kepada Masyarakat ini menyimpulkan bahwa; (1) seluruh target capaian terpenuhi, (2) tingkat pengetahuan dan keterampilan modifikasi Permainan Olahraga Anak 90\%, (3) dan tingkat kepuasan pelaksanaan kegiatan sebesar $88,5 \%$.
\end{abstract}

Keywords: Modification, Elementry School, Athletic Kids

\begin{abstract}
Community Partnership Program activity partners are a working group of physical education teachers in Tebing Tinggi city which is $60 \mathrm{~km}$ from Universitas Negeri Medan. Physical Education Teacher Sports Health Elementary School level in the City Tebing Tinggi have some learning process problems so that the tendency to learn quality of Physical Education Sports Health has not been maximal. The partner issues faced during this time are: (1) Lack of knowledge and skills of The Physical Education Teacher Working Group of Primary School Health Sports in modifying Sports Equipment for students and athletics kids, their use in games and analysis of game results data, and (2) There are no sports equipment available in schools in partner sub-districts that can be used to assist the learning process of elementary school physical education. Both problems are the basis that physical education learning of health sports is not optimal. The methods that will be used in this activity are Mentoring and empowerment. The following stages of activity: 1) Provision of Children's Sports Games, (2) Training of Athletic Kids Implementation and assessment techniques (3) Modified Training of Children's Sports Games, (4) Training on the use of modified Children's Sports Games and (5) Kids Athletics Competitions. Results of activities : (1) Children's Sports Games have been accepted by the chairman of the Working Group of Teachers of Physical Education Sports Health Elementary School Tebing Tinggi, (2) The achievability of children's sports games $92.5 \%$, (3) Achieved $89.5 \%$ assessment indicator scoring of Children's Sports Games, and (4) 93\% reachability of
\end{abstract}


children's sports games. This Community Service activity program concludes that; (1) all achievement targets are met, (2) the level of knowledge and skills of modification of Children's Sports Games 90\%, (3) and the satisfaction rate of the implementation of activities is $88.5 \%$.

Keywords: Modification, Elementry School, Athletic Kids

\section{PENDAhuluan}

Yang menjadi permasalahan dalam kegiatan Program Kemitraan Masyarakat (PKM) pada kelompok kerja guru pendidikan jasmani kota Tebing Tinggi selama ini adalah (1) ketersedian \& kesediaan Peralatan Olahraga di Sekolah, (2) guru kurang mampu dalam memodifikasi Peralatan Olahraga di sekolah, (3) guru PJOK cenderung kurang menggunakan media pembelajaran visual karena tidak mampu mengoperasionalkan komputer.

Permasalahan di atas menjadi dasar untuk menentukan arah potensi selanjutnya dalam bidang olahraga sehingga diyakini dapat memecahkan permasalahan mitra yang sejak lama tidak diselesaikan sehingga dirasa sangat penting untuk dilakukan kegiatan peningkatan kualitas pembelajaran KKG PJOK SD di dua kecamatan kota Tebing Tinggi. Jika keadaan ini tidak segera diatasi maka mutu pembelajaran PJOK di SD terus menurun terhadap kualitas pembelajaran.

Dari permasalahan yang terjadi tersebut dimana dengan melalui pembinaan multilateral diharapkan anak mendapatkan pondasi gerak yang lebar sehingga memungkinkan anak untuk memiliki keterampilan bergerak secara menyeluruh dan menjadi dasar untuk menentukan arah potensi selanjutnya dalam bidang olahraga. Selanjutnya dengan memberikan pembelajaran melalui media visual dan modifikasi peralatan olahraga. Kegiatan Program Kemitraan Masyarakat (PKM) bagi Kelompok Kerja Guru (KKG) PJOK bertujuan untuk: 1) meningkatkan pengetahuan dan keterampilan mitra tentang pembuatan modifikasi peralatan olahraga anak atau atletik kids, 2) menyediakan fasilitas POA bagi mitra, 3) melatih mitra untuk dapat menggunakan atketik kids dan dapat membuat program peralatan lain secara mandiri. 4) Menjadikan POA sebagai wirausaha baru bagi mitra PKM

\section{BAHAN DAN METODE}

Perlengkapan POA disusun dalam sebuah paket/set yang berisi 5 jenis peralatan yang dapat digunakan untuk melakukan berbagai jenis kegiatan jasmani dan olahraga seperti gerak lari, lompat, lempar (atletik), dan kegiatan jasmani lain yang dapat diciptakan dengan menggunakan alat tersebut. Adapun komponen alat yang utama yang ada dalam perlengkapan POA ini yaitu; (1) tas peralatan, (2) simpai ketangkasan, (3) kotak lompat, (4) roket/rudal, (5) gawang aman, yang mana semua komponen alat tersebut bermerek POA Multilateral.

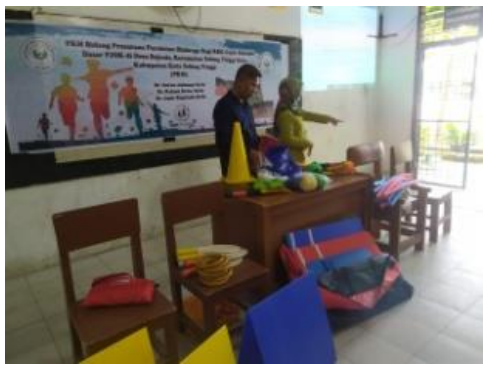

Gambar 1. Perlengkapan Peralatan Olahraga Anak (Sumber:dokumen pribadi)

Metode yang digunakan dalam program PKM ini adalah model pemberdayaan dengan langkah-langkah sebagai berikut : (1) Tahap Persiapan; pada tahap ini melakukan koordinasikan dengan LPM-UNIMED dan tim mitra dan Instansi yang terkait seperti pengurusan surat ijin, penyusunan jadwal kegiatan dan persiapan pembuatan pembuatan peralatan atletik Kids yang akan diberikan kepada Tim Mitra. Tahapan persiapan untuk pembuatan fasilitas permainan edukasi adalah meliputi inventarisasi peralatan yang akan digunakan, dan perancangannya serta dianalisa seluruh aspek yang diperlukan untuk keamanan alat. (2) Tahap Assesment, yang mana dalam tahap ini memberikan pelatihan langsung kepada mitra, bagaimana menggunakan peralatan yang ada, serta mekanisme kerja alat, dan bentuk permainan atletik kids serta cara menganalisis data hasil skor total dari bagian-bagian nomor lomba;(3) Tahap Perencanaan Alternatif Program atau Kegiatan yang mana pada tahap ini kegiatan yang dilakukan adalah melakukan pendampingan melalui beberapa aktivitas diantaranya; (a) merancang berbagai peralatan atletik kid yang merupakan modifikasi dari peralatan standar; (b) merancang berbagai bentuk permainan olahraga anak berbasis pengembangan gerak multilateral serta yang mengandung unsur play dan games; (4) Tahap Pemformulasian Rencana Aksi, dalam tahap ini memberikan wawasan tentang strategi bagaimana merintis dan mengembangkan usaha bagi KKG mata pelajaran PJOK berkenaan dengan manajemen Usaha dan Manajemen Pemasaran; (5) Tahap Pelaksanaan (Implementasi) Program atau Kegiatan, dalam tahap ini adapun kegiatan pelaksanaan yang dilakukan adalah melakukan game terhadap siswa dengan menggunakan 
peralatan olahraga anak yang telah dijelaskan dari penggunaan alat tersebut; (6) Tahap Evaluasi; pada tahap evaluasi dilakukan dengan 3 tahap, adapun tahap tersebut, (a) Tahap awal yang mana dalam tahap ini mengukur tingkat keberhasilan dari motivasi yang telah diberikan, (b) Tahap proses kegiatan yang mana dalam tahap ini untuk mengetahui kemampuan Tim Mitra mengimplimentasikan seluruh materi pelatihan yang telah diberikan oleh tim pakar, (c) Tahap akhir dimana dalam tahap ini melihat keberhasilan dari kegiatan yang telah dilaksanakan yang diindikasikan dengan kemampuan mitra dalam mengoperasikan Peralatan Atletik Kid dan kegunaannya serta hasil produksi. Dan yang terakhir (7) Tahap Terminasi; pada tahap ini dilakukan pemantauan setelah kegiatan selesai apakah berjalan sesuai dengan yang diharapkan.

\section{HASIL DAN PEMBAHASAN}

\section{Penyerahan Permainan Olahraga Anak}

Dalam pelaksanaan PKM dimana penyerahan Permainan Olahraga Anak diterima oleh Ketua Kelompok Kerja Guru Pendidikan Jasmani Olahraga Kesehatan Sekolah Dasar Kota Tebing Tinggi, dalam hal ini penyerahan Permainan Olahraga Anak dihadiri oleh tim monev dari LPPM-UNIMED beserta peserta yang mengikuti kegiaan pelatihan, untuk lebih jelasny dapat dilihat pada gambar no.2 dibawah ini.

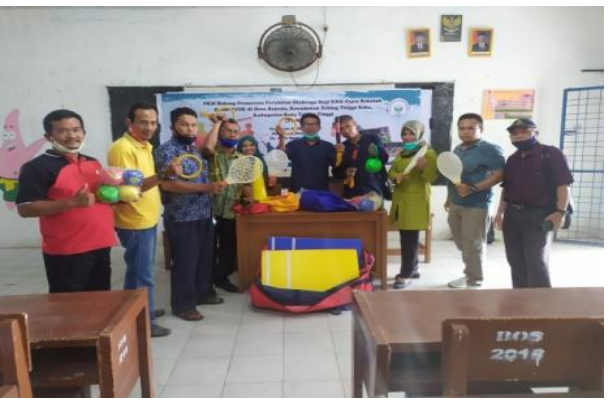

Gambar 2. Penyerahan dan Perlengkapan Peralatan Olahraga Anak (Sumber:dokumen pribadi)

\section{Pelatihan penggunaan Permainan Olahraga Anak}

Tabel.1. Pelatihan Penggunaan POA

\begin{tabular}{clccccccccccc}
\hline No & Indikator & $\mathbf{1}$ & $\mathbf{2}$ & $\mathbf{3}$ & $\mathbf{4}$ & $\mathbf{5}$ & $\mathbf{6}$ & $\mathbf{7}$ & $\mathbf{8}$ & $\mathbf{J m l}$ & $\mathbf{J m l}$ & $\mathbf{X}$ \\
\hline 1 & $\begin{array}{l}\text { Kemudahan } \\
\text { menggunakan } \\
\text { alat }\end{array}$ & 4 & 5 & 4 & 5 & 5 & 5 & 4 & 4 & 36 & 40 & 90 \\
\hline 2 & $\begin{array}{l}\text { Keamanan } \\
\text { Menggunakan } \\
\text { alat }\end{array}$ & 4 & 5 & 5 & 4 & 4 & 5 & 5 & 5 & 37 & 40 & 92.5 \\
\hline 3 & $\begin{array}{l}\text { Manfaat } \\
\text { penggunaan } \\
\text { alat }\end{array}$ & 4 & 4 & 5 & 5 & 5 & 5 & 5 & 5 & 38 & 40 & 95 \\
\hline 4 & $\begin{array}{l}\text { Kemahiran } \\
\text { dalam } \\
\text { menggunakan }\end{array}$ & 4 & 4 & 5 & 5 & 5 & 5 & 5 & 5 & 38 & 40 & 95 \\
\hline 5 & $\begin{array}{l}\text { Pembelajaran } \\
\text { semakin } \\
\text { menarik }\end{array}$ & 4 & 4 & 4 & 4 & 5 & 5 & 5 & 5 & 36 & 40 & 90 \\
\hline & JUMLAH & 20 & 22 & 23 & 23 & 24 & 25 & 24 & 24 & 185 & 200 & 92.5 \\
\hline
\end{tabular}

Berdasarkan hasil analisis dari 8 guru yang melakukan percobaan penggunaan Peralatan Permainan Olahraga Anak, dimana diberikan 5 (lima) indicator. indicator tersebut: 1) Kemudahan menggunakan alat diketahui jumlah total skor responden $\left(\sum \mathrm{X}\right)$ adalah $\mathbf{3 6}$ dan jumlah total keseluruhan skor responden $\left(\sum X\right)$ adalah 40 sehingga, persentasenya adalah 90\%. 2) keamanan menggunakan alat diketahui jumlah total skor responden $\left(\sum X\right)$ adalah $\mathbf{3 7}$ dan jumlah total keseluruhan skor responden $\left(\sum X\right)$ adalah $\mathbf{4 0}$ sehingga, persentasenya adalah 93\%. 3) Manfaat menggunakan alat diketahui jumlah total skor responden $\left(\sum \mathrm{X}\right)$ adalah $\mathbf{3 8}$ dan jumlah total keseluruhan skor responden $\left(\sum X\right)$ adalah $\mathbf{4 0}$ sehingga, persentasenya adalah 95\%. 4) Kemahiran dalam menggunakan alat diketahui jumlah total skor responden $\left(\sum X\right)$ adalah $\mathbf{3 8}$ dan jumlah total keseluruhan skor responden $\left(\sum \mathrm{X}\right)$ adalah $\mathbf{4 0}$ sehingga, persentasenya adalah 95\%. 5) Pembelajaran semakin menarik diketahui jumlah total skor responden $\left(\sum \mathrm{X}\right)$ adalah $\mathbf{3 7}$ dan jumlah total keseluruhan skor responden $\left(\sum X\right)$ adalah 40 sehingga, persentasenya adalah $\mathbf{9 3 \%}$.

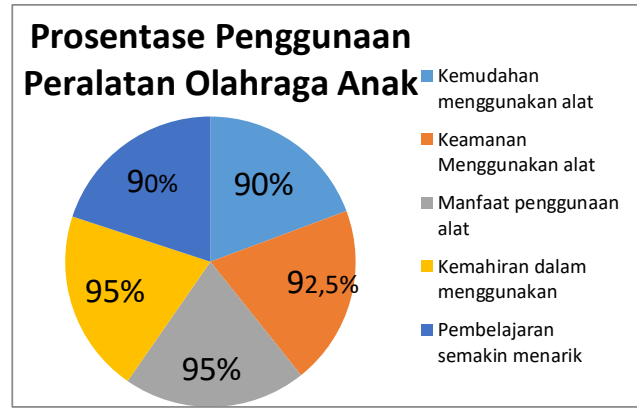

Diagram 1. Prosentase Modifikasi Permainan Olahraga Anak

Pelatihan Penilaian Permainan Olahraga Anak

Tabel.2. Pelatihan Penilaian POA

\begin{tabular}{|c|c|c|c|c|c|c|c|c|c|c|c|c|}
\hline \multirow{2}{*}{ No } & \multirow{2}{*}{ Indikator } & \multicolumn{8}{|c|}{ Skala Penilaian } & \multirow{2}{*}{ Jml } & \multirow{2}{*}{$\begin{array}{c}\mathbf{J m l} \\
\mathbf{X i}\end{array}$} & \multirow{2}{*}{$\%$} \\
\hline & & 1 & 2 & 3 & 4 & 5 & 6 & 7 & 8 & & & \\
\hline 1 & $\begin{array}{l}\text { Kemudahan } \\
\text { menggunakan } \\
\text { alat dalam } \\
\text { perlombaan }\end{array}$ & 4 & 5 & 4 & 5 & 5 & 5 & 4 & 4 & 36 & 40 & 90 \\
\hline 2 & $\begin{array}{l}\text { Keamanan } \\
\text { alat dalam } \\
\text { perlombaan }\end{array}$ & 4 & 5 & 5 & 4 & 4 & 5 & 5 & 5 & 37 & 40 & 92.5 \\
\hline 3 & $\begin{array}{l}\text { Kelayakan } \\
\text { POA dalam } \\
\text { perlombaan }\end{array}$ & 4 & 4 & 5 & 5 & 5 & 5 & 5 & 5 & 38 & 40 & 95 \\
\hline 4 & $\begin{array}{c}\text { Kesesuaian } \\
\text { alat dengan } \\
\text { mobilitas } \\
\text { pengguna }\end{array}$ & 4 & 4 & 5 & 5 & 5 & 5 & 5 & 5 & 38 & 40 & 95 \\
\hline 5 & $\begin{array}{c}\text { Cara } \\
\text { Melakukan }\end{array}$ & 4 & 4 & 4 & 4 & 5 & 5 & 5 & 5 & 36 & 40 & 93 \\
\hline & JUMLAH & 20 & 22 & 23 & 23 & 24 & 25 & 24 & 24 & 185 & 200 & 89.5 \\
\hline
\end{tabular}

Berdasarkan hasil analisis dari 8 guru yang melakukan percobaan penggunaan Peralatan Permainan Olahraga Ramah Anak, dimana diberikan 5 (lima) indicator, indicator tersebut: 1) Kemudahan 
menggunakan alat dalam perlombaan diketahui jumlah total skor responden $\left(\sum \mathrm{X}\right)$ adalah $\mathbf{3 6}$ dan jumlah total keseluruhan skor responden $\left(\sum X\right)$ adalah 40 sehingga, persentasenya adalah $\mathbf{9 0 \%}$. 2) keamanan menggunakan alat dalam perlombaan diketahui jumlah total skor responden $\left(\sum X\right)$ adalah $\mathbf{3 7}$ dan jumlah total keseluruhan skor responden $\left(\sum X\right)$ adalah $\mathbf{4 0}$ sehingga, persentasenya adalah 93\%. 3) Kelayakan Penggunaan POA dalam perlombaan diketahui jumlah total skor responden $\left(\sum X\right)$ adalah 38 dan jumlah total keseluruhan skor responden $\left(\sum X\right)$ adalah 40 sehingga, persentasenya adalah 95\%.4) Kesesuaian alat dengan mobilitas anak, diketahui jumlah total skor responden $\left(\sum \mathrm{X}\right)$ adalah $\mathbf{3 8}$ dan jumlah total keseluruhan skor responden $\left(\sum X\right)$ adalah 40 sehingga, persentasenya adalah 95\% . 5) Cara perlakuan diketahui jumlah total skor responden $\left(\sum X\right)$ adalah $\mathbf{3 7}$ dan jumlah total keseluruhan skor responden $\left(\sum \mathrm{X}\right)$ adalah $\mathbf{4 0}$ sehingga, persentasenya adalah $\mathbf{9 3 \%}$.

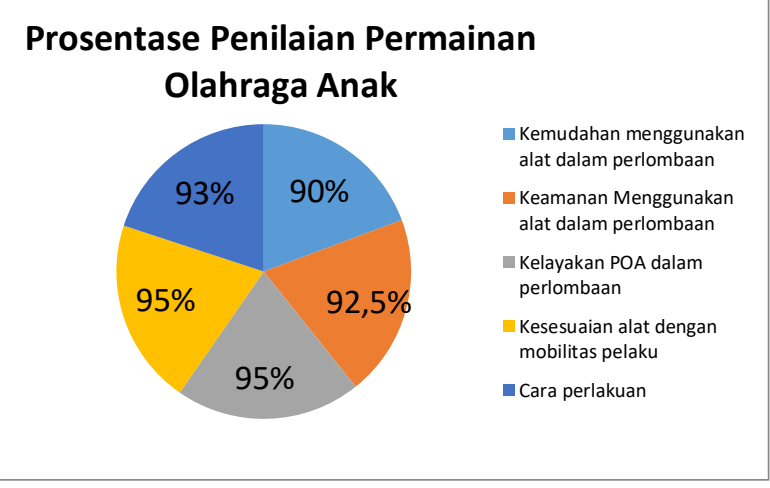

Diagram 2. Prosentase Penilaian Permainan Olahraga Anak

\section{Pelatihan Modifikasi Permainan Olahraga Anak}

\begin{tabular}{|c|c|c|c|c|c|c|c|c|c|c|c|c|}
\hline \multirow{2}{*}{ No } & \multirow{2}{*}{ Indikator } & \multicolumn{8}{|c|}{ Skala Penilaian } & \multirow{2}{*}{ Jml } & \multirow{2}{*}{$\underset{\mathbf{X i}}{\mathbf{J m l}}$} & \multirow{2}{*}{$\%$} \\
\hline & & 1 & 2 & 3 & 4 & 5 & 6 & 7 & 8 & & & \\
\hline 1 & $\begin{array}{l}\text { Kemudahan } \\
\text { memodifikasi } \\
\text { alat ramah anak }\end{array}$ & 4 & 5 & 4 & 5 & 5 & 5 & 4 & 4 & 36 & 40 & 90 \\
\hline 2 & $\begin{array}{l}\text { Hasil yang } \\
\text { dicapai setelah } \\
\text { memodifikasi } \\
\text { alat ramah anak }\end{array}$ & 4 & 5 & 5 & 4 & 4 & 5 & 5 & 5 & 37 & 40 & 92.5 \\
\hline 3 & $\begin{array}{l}\text { Tingkat } \\
\text { pengetahuan } \\
\text { dalam } \\
\text { memodifikasi } \\
\text { alat ramah anak } \\
\end{array}$ & 4 & 4 & 5 & 5 & 5 & 5 & 5 & 5 & 38 & 40 & 95 \\
\hline 4 & $\begin{array}{l}\text { Alur dalam } \\
\text { memodifikasi } \\
\text { alat ramah anak }\end{array}$ & 4 & 4 & 5 & 5 & 5 & 5 & 5 & 5 & 38 & 40 & 95 \\
\hline 5 & $\begin{array}{l}\text { Cara } \\
\text { Melakukan } \\
\text { modifikasi }\end{array}$ & 4 & 4 & 4 & 4 & 5 & 5 & 5 & 5 & 36 & 40 & 90 \\
\hline & JUMLAH & 20 & 22 & 23 & 23 & 24 & 25 & 24 & 24 & 185 & 200 & 93 \\
\hline
\end{tabular}

Tabel.3. Pelatihan Modifikasi POA

Berdasarkan hasil analisis dari 8 guru yang melakukan percobaan penggunaan Peralatan Permainan
Olahraga Ramah Anak, dimana diberikan 5 (lima) indicator, indicator tersebut: 1) Kemudahan menggunakan alat dalam perlombaan diketahui jumlah total skor responden $\left(\sum \mathrm{X}\right)$ adalah $\mathbf{3 6}$ dan jumlah total keseluruhan skor responden $\left(\sum X\right)$ adalah 40 sehingga, persentasenya adalah $\mathbf{9 0 \%}$. 2) keamanan menggunakan alat dalam perlombaan diketahui jumlah total skor responden $\left(\sum X\right)$ adalah $\mathbf{3 7}$ dan jumlah total keseluruhan skor responden $\left(\sum X\right)$ adalah $\mathbf{4 0}$ sehingga, persentasenya adalah 92,5\%. 3) Kelayakan Penggunaan peralatan permaina olahraga ramah anak dalam perlombaan diketahui jumlah total skor responden $\left(\sum \mathrm{X}\right)$ adalah $\mathbf{3 8}$ dan jumlah total keseluruhan skor responden $\left(\sum X\right)$ adalah 40 sehingga, persentasenya adalah 95\%. 4) Kesesuaian alat dengan mobilitas anak, diketahui jumlah total skor responden $\left(\sum \mathrm{X}\right)$ adalah $\mathbf{3 8}$ dan jumlah total keseluruhan skor responden $\left(\sum X\right)$ adalah 40 sehingga, persentasenya adalah $\mathbf{9 5 \%}$. 5) Cara perlakuan diketahui jumlah total skor responden $\left(\sum X\right)$ adalah $\mathbf{3 7}$ dan jumlah total keseluruhan skor responden $\left(\sum X\right)$ adalah $\mathbf{4 0}$ sehingga, persentasenya adalah $\mathbf{9 0 \%}$.

\section{Prosentase Modifikasi Peralatan Permainan Olahraga Anak}

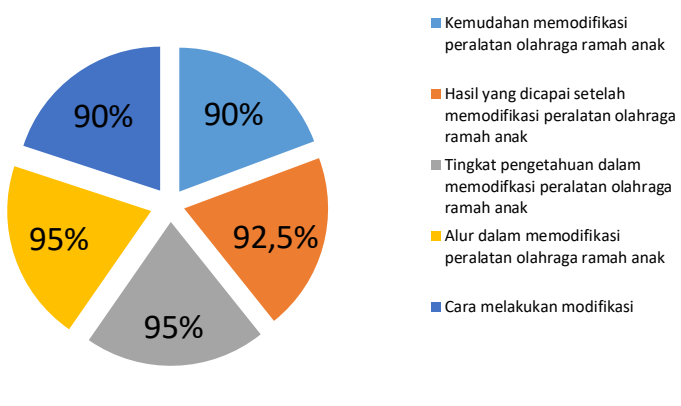

Diagram 3. Prosentase Modifikasi Peralatan Permainan Olahraga Anak

Kegiatan Pengabdian Kepada Masyarakat ini menyimpulkan bahwa ; (1) seluruh target capaian terpenuhi sebesar $95 \%$, (2) tingkat pengetahuan dan keterampilan modifikasi Permainan Olahraga Anak $90 \%$, (3) dan tingkat kepuasan pelaksanaan kegiatan sebesar $88,5 \%$.

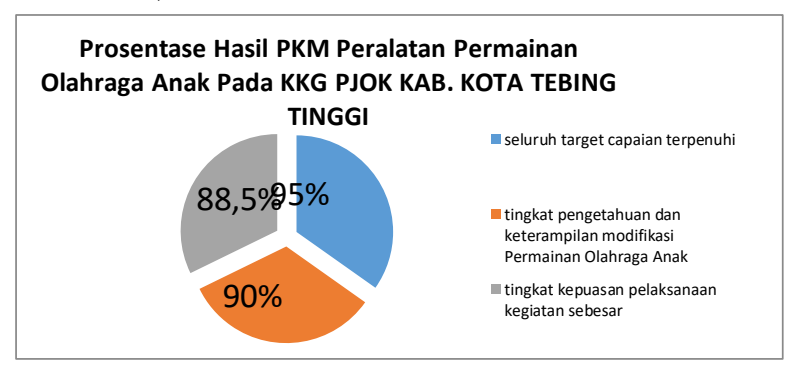

Diagram 4. Hasil PKM Peralatan Oahraga Anak pada KKG 
PJOK Kab. Kota Tebing Tinggi

\section{KESIMPULAN}

Hasil laporan akhir pengabdian kepada masyarakat yang telah dilaksanakan telah mencapai $100 \%$. Selanjutnya kegiatan ini diharapkan dapat menumbuhkan jiwa wirausaha baru yang dapat membantu perekonomian KKG PJOK sendiri dan sekolah tempat bekerja khususnya pengadaan peralatan olahraga anak yang standar dan ramah anak dengan memanfaatkan kearifan lokal di Kabupaten Kota Tebing Tinggi.

\section{UCAPAN TERIMA KASIH}

Selanjutnya dalam kegiatan ini kami yang terlibat dalam pelaksanaan pengabdian kepada masyarakat (PKM) mengucapkan banyak terimakasih kepada Universitas Negeri Medan dibawah naungan LPPM UNIMED yang telah membatu dalam hal pendanaan sehingga proses pelaksanaan pengabdian ini dapat berjalan dengan lancar seperti yang kita harapkan. Selain itu juga kepada tim KKG PJOK Kab. Kota Tebing Tinggi beserta mahasiswa yang telah meluangkan waktunya untuk kelancaran proses peaksanaan pengabdian ini sampai dengan selesai seperti yang diharapkan.

\section{DAFTAR PUSTAKA}

Charles Gozzali, dkk, (2014), IAAF Kids Athletik a Team For Children A Practice Guide Kids Athletic Animator, International Association of Athletic Federation.

LPPM UNIMED (2019). Panduan Pelaksanaan Penelitian dan Pengusulan Masyarakat Sumber dana PNBP/BOPTN dan Mandiri Unimed

Gani Eka Gustanto (2014), Survei Peralatan Olahraga Anak (POA) di Sekolah Dasar Se Gugus Dipanegara Kecamatan Sigaluh Kabupaten Barjarnegara, e-Journal Universitas Negeri Yogyakarta.

Masmar (2010), Pedoman Atletik Kids, blog.UNY.ac,id, 2-12-2010

Panji Nugraha, Rumini, Uen Hartiwan (2013), Model Pembelajaran Penjasorkes Kids Atletik Melalui Permainan The Strength Post Pada Siswa Sd Kelas V. Journal of Physical Educations, Sport, Health and Recreation, Vol. 2 Nomor 8 tahun 2013.

Ria Lumintuarso (2015) Peralatan Olahraga Anak untuk Pengembangan Multilateral. Yogyakarta: Yogyakarta Press. 